\title{
Malignant Ureter Neoplasm
}

National Cancer Institute

\section{Source}

National Cancer Institute. Malignant Ureter Neoplasm. NCI Thesaurus. Code C7543.

A primary or metastatic malignant tumor involving the ureter. The majority are

carcinomas. -- 2003 